\title{
Southern Somalia's “Glorious Days Are Our Nightmare": The Performance of Political Memory and Contestations of Commemoration in Northern Somalia (Somaliland)
}

\begin{abstract}
This chapter makes a critical intervention into the academic and popular discussions about political memory in Somalia. Focusing on contestations of political memory and disputes over what occurred in the past as well as why, when and where they took place, the chapter foregrounds the importance of memory and commemoration for the Somaliland state-building project. By presenting a new perspective on the making of the breakaway region in northern Somalia that declared itself independent Somaliland in 1991, the chapter offers insights into how memories of trauma function as a political resource that could crystallise conflict and confrontation. Furthermore, in the case observed, judicious deployment of political memory elicited sympathy and solidarity locally and amongst diasporic Somaliland people in the pursuit of the separatist state-building project in Somaliland. Drawing on fieldwork conducted in Somaliland at intervals between 2016, 2018 and 2019 that relied on ethnographic observations and interviews with men and women, the chapter explores how the independence project in Somaliland was constructed through accumulated collective historical grievances. These were used to strengthen the case in favour of seeking recognition for a separate state allowing the collapse of the Somali state. Supposedly collective community suffering was rooted in how the military regime - bent on the protection and preservation of specific clans - mistreated the Isaaq, the predominate clan in Somaliland. Building upon previous studies of political memory, the chapter reveals how particularistic historical grievance shaped - and continues to shape - the process of legitimising separatism in Somaliland.
\end{abstract}

On one early evening at the end of April 2018, Hassan Mohamud Dagaal "Jaafaa," a grey-haired, middle-aged, former soldier living in Gebiley, a small town located 58 kilometres west of Hargeysa, the capital of northern Somalia (in the autonomous region of Somaliland), sat with me for an interview. He recollected 
the horrific days that aptly characterise the last decade of the military regime under General Mohamed Siad Barre, who ruled Somalia between October 1969 and January 1991. ${ }^{1}$ Jaafaa, employed as a bodyguard of a notorious senior army officer during the 1980s, began to recall key locations and incidents under his watch. He sobbed while recounting his experiences. The most harrowing incident that still haunts him took place in 1981. Yusuf Abdi Ali, nicknamed "Tukeh," then a Lieutenant Colonel in Siad Barre's army, was transferred to the northern $26^{\text {th }}$ military sector where he was given instruction to lead the Fifth Brigade. Tukeh had just returned from the United States where he had undertaken a three-month intensive course in military high command. Upon his return, Tukeh suddenly separated his brigade along clan lines: Isaaq and nonIsaaq. The Isaaq were then, as they are now, the predominant clan in Somaliland. Jaafaa recollected that 180 Isaaq men were lined up, disarmed, and their weapons shelved. They were subsequently taken to prison and treated like hostages. ${ }^{2}$ In the end, 82 of them were released, but the rest disappeared. They were last seen somewhere between Hargeysa and Gebiley. Jaafaa knew nothing of their whereabouts. Those who were lucky enough to have been spared this "disappearance" were saved by non-Isaaq military officers who claimed to have been related to them in one way or another. "We committed no crime," Jaafaa, himself an Isaaq, said with a soft voice. ${ }^{3}$ The US-based Center for Justice and Accountability fought for years on behalf of Isaaq victims to bring Tukeh who now lives in Virginia to justice in US courts. ${ }^{4}$

In contemporary news reports as well as in much of the existing academic literature, substantial attention is given to the fall of the military regime in January 1991, when the regime was ousted and all state structures disintegrated as a result of a popular uprising that rocked the capital city Mogadishu in December 1990. Especially during the 1980s, Siad Barre's military regime left an enduring legacy of pain, which is regularly and repeatedly recounted in local and diaspor-

1 Interview with Hassan Mohamud Dagaal “Jaafaa,” Gebiley, Somaliland, 27 April 2018.

2 Ibid.

3 Ibid. Author's translation. See also "Pointers - Somalia: Siad Barre’s Foes,” Africa Confidential 22, no. 9 (22 April 1981): 7; "Somalia: Somalia Barre Hangs on,” Africa Confidential 24, no. 5 (2 March 1983): 5-7; and "Somalia: Generals on the Move," Africa Confidential 25, no. 10 (9 May 1984): $7-8$.

4 The Center for Justice and Accountability, "Mass Atrocities in Northern Somalia: Warfaa V. Ali (Col. Tukeh)," accessed 13 September 2018, https://cja.org/what-we-do/litigation/warfaa-v-alicol-tukeh/. 
ic Somali communities, both in private and in public as well as political debate. ${ }^{5}$ Similar to conflict-ridden contexts elsewhere on the African continent at the end of the Cold War, such as the Congo where political fissions gave way to violence, ${ }^{6}$ the era witnessed state collapse and clan warfare in Somalia. This volatile situation made it difficult for victims of state crimes committed in the 1980s to receive any redress. The repercussions included political violence becoming not only an ordinary occurrence, but also a socially accepted form of expressing contestation for power amongst various armed groups. Although the implications of the war are often debated in popular media outlets, academic literature on the politics of memory remains almost non-existent in Somali studies. ${ }^{7}$ Given that memories of the "civil" war remain central to divisions in Somali national identity, it is surprising that the intersection of memory, state power, politics and history has received little attention in scholarship on Somalia. Thus, fundamental questions remain: what scars do violent military regimes leave and why? How do political memories influence and shape post-conflict war-torn societies, state-building, and avenues of redress? Also, in which ways are specific political memories being challenged?

This chapter presents a new perspective on the making of the breakaway region in northern Somalia that declared itself independent Somaliland. It focuses on contestations of political memory and disputes over what occurred in the past as well as why, when and where they took place. Drawing on fieldwork conducted in Somaliland during July and August 2016, April and May 2018 and November and December 2019 using ethnographic observations and interviews with men and women, the chapter offers insights into how memories of trauma function as a political resource that could crystallise conflict and confrontation. Furthermore, in the case observed, judicious deployment of political memory elicited sympathy and solidarity locally and in the diaspora among the Isaaq elites in

5 For a detailed study on the politics, policies, practices and performances of the military regime, see Mohamed Haji Ingiriis, The Suicidal State in Somalia: The Rise and Fall of the Siad Barre Regime, 1969-1991 (Lanham, MD: University Press of America, 2016).

6 Michael Niemann, "War Making and State Making in Central Africa," Africa Today 53, no. 3 (2007): 21-39.

7 There are only a few exceptions. See Francesca Declich, "When Silence Makes History, Gender and Memories of War Violence from Somalia," in Anthropology of Violence and Conflict, eds. Bettina Schmidt and Ingo Schröder (London: Routledge, 2001), 161-175; Mohamed Haji Ingiriis, "Many Somalia(s), Multiple Memories: Remembrance as Present Politics, Past Politics as Remembrance," African Identities 14, no. 1 (2016): 348-369; Mohamed Haji Ingiriis, "How Somalia Works: Mimicry and the Making of Mohamed Siad Barre's Regime in Mogadishu," Africa Today 63, no. 1 (2016): 57-83; and Mohamed Haji Ingiriis, "State Violence and Clan Violence in Somalia,” African Conflict and Peacebuilding Review 8, no. 1 (2018): 73-96. 
the pursuit of the separatist state-building project in Somaliland. ${ }^{8}$ The local elites in Somaliland are diverse but they are primarily dominated by Isaaq who consist of political players and businessleaders, many of whom returned from the diaspora. Because Somaliland was constructed through accumulated collective historical grievances, local elites drew on these aspects of political memory to strengthen the case in favour of seeking recognition for a separatist state allowing the collapse of the Somali state - an especially viable option given the new international order post-1990. Supposed collective community suffering was rooted in how the military regime, bent on the protection and preservation of specific clans, mistreated the Isaaq clan in particular.

Building on previous studies of political memory, the chapter reveals how particularistic historical grievance shaped - and continues to shape - the process of legitimising the state in Somaliland. ${ }^{9}$ At the same time non-Isaaq inhabitants of Somaliland, as well as regular people and the younger generation, have challenged this process of legitimisation. To blend the past with the present so as to interrogate the power and politics of memory as it attached to the separatist statehood, the chapter adopts historical as well as contemporary comparative approaches. ${ }^{10}$ Historian Arno Mayer contends that the "comparative perspective helps to broach new questions, such as the role of vengeance; to bring to light and challenge unspoken scholarly assumptions, such as the anomaly and mon-

\footnotetext{
8 It should be noted that the Isaaq elites abhor the term "secessionism" contending that Somaliland did not secede from Somalia, but rather had reclaimed sovereignty. The term "separatism," which also suggests something similar to secessionism, is also not appreciated, but this study opts to use it anyway. Field interviews and observations in Hargeysa, November-December 2019. 9 The concept of political memory has different meanings that have been used in various ways. See Ifi Amadiume and Abdullahi An-Na'im, eds., The Politics of Memory: Truth, Healing \& Social Justice (London: Zed Books, 2000); James M. Mayo, "War Memorials as Political Memory," Geographic Review 78, no. 1 (1988): 62-75; and Susana Kaiser, "Escraches: Demonstrations, Communication and Political Memory in Post-Dictatorial Argentina," Media, Culture and Society 24, no. 4 (2002): 499-516.

10 My late supervisor Jan-Georg Deutsch taught me how to compare and to contrast historical circumstances, which has left a deep influence on my approach to researching the present and past history of Somali society. My own positionality as a researcher, especially one from southern Somalia doing research in northern Somalia (Somaliland) did not lead to a perception that I was "part of the story," apparently because my family was not affiliated with the military regime. As Catherine Besteman points out that, 'A primary goal of anthropological fieldwork is to gain an understanding of how those being studied make sense of their world'. Catherine Besteman, Making Refuge: Somali Bantu Refugees and Lewiston, Maine (Durham: Duke University Press, 2016), 7.
} 
strosity of violence."11 Besides, and with particular relevance for this volume, comparative analysis, Mayer argues, "facilitates identifying the importance of historical legacies and memories."12

In contrast to southern Somalia where diverse competing groups still vie for power, the Isaaq elites in Somaliland have sought to coalesce around a separation project bolstered by clan-based historical grievances. Even if this has not always been a smooth process in terms of nation-building, of late the Somaliland state-building project has made progress. The unrecognised state in Somaliland, unlike the recognised state in southern Somalia, was legitimised on the basis of a narrative of clan-based victimhood that has unsurprisingly struggled to attract a wider communal and cohesive solidarity apart from the Isaaq clan, an indication of failure to bring about one national identity inclusive of other groups living in Somaliland.

Identifying how memory and commemoration are used to reframe clan identities, the chapter assesses contested political memory by exploring the historical group grievances upon which the Isaaq base their advocacy for existence as a state separate from the rest of Somalia. It is argued that historical grievances not only lay at the heart of separation from southern Somalia, but more importantly, through contested and conflicting political memories, continue to stabilise and legitimise the separatist state in the eyes of the Isaaq population. This is not because the Isaaq population is more prone to refer to grievancebased political memory than other clans in Somaliland, but because a dominant Isaaq group portrays other Somalis, especially those from southern Somalia, as oppressors as a result of the atrocities committed during the latter years of the Barre era. ${ }^{13}$ The conclusion from historian Uzi Rabi on tribal societies - according to which the state in clan conflicts is not a "political actor" but a "political field" - is relevant in this case. ${ }^{14}$ As Marleen Renders observed of Somaliland, the state and the clan have proven to be "part of the same story, part of the same political dynamics." 15 The interplay between the state and the clan came to follow what Carole Nagengast calls "a dialectical relationship."

11 Arno J. Mayer, The Furies: Violence and Terror in the French and Russian Revolution (Princeton: Princeton University Press, 2000), 14.

12 Ibid.

13 Field interviews and observations in Hargeysa, April-May 2018.

14 Cited in Alice Hills, "Somalia Works: Police Development as State Building," African Affairs 113, no. 945 (2014): 92.

15 Marleen Renders, Consider Somaliland: State-Building with Traditional Elders and Institutions (Leiden: Brill, 2012), 57. 
To make these arguments, this chapter will briefly discuss political memory in relation to Somaliland from a theoretical perspective. It will then detail the historical background that forms the basis for the formulation of these political memories. The final two sections consider the construction of identity as people of Somaliland and how this construction is being challenged, followed by a brief conclusion.

\section{Political Memory, Grievance and Commemoration}

Post-colonial-states are constructed through a selection of myriad memories and sustained on contextual commemoration. Casper Andersen's chapter in this volume, as well as that of Ed Goodman's, are pertinent here by analysing decolonisation and political memory. The preservation of a political memory creates a baseline for the state to foster solidarity within its citizenry. In examining the politics of memory in Eritrea, Daniel Mekonnen reveals how specific, selective, and contested memories of the past in Asmara are preserved to promote postconflict state-building. ${ }^{17}$ Moreover, political memory plays a decisive role in forming and constructing states within states, where antagonism between local communities and the state exist, as for instance in a conflict-ridden political landscape. Discussing the memorialisation policies of the Western Balkans, Israel and Palestine, Lee David argues that "memory construction is quite often used to define and reinforce [political] boundaries."18

Political memory also blends group grievances in the context of severely war-torn settings. In the case of conflict and post-conflict settings, Ernest Renan emphasised that "griefs are of more value than triumphs, for they impose duties, and require a common effort." ${ }^{19}$ Political memory in war-torn societies can be more heavily contested than in societies unburdened by violent conflict. People memorialise the aftermath of a war differently through various groups, subgroups and close-knit communities. As evident in Natacha Filippi's chapter in this volume, public communal outcry against and close community-held

16 Carole Nagengast, "Violence, Terror, and the Crisis of the State," Annual Review of Anthropology 23 (1994): 117.

17 Daniel Mekonnen, “Contested Versions of Collective Memory in Postindependence Eritrea," African Conflict \& Peacebuilding Review 3, no. 2 (2013): 151-170.

18 Lee David, "Holocaust and Genocide Memorialisation Policies in the Western Balks and Israel/Palestine," Peacebuilding 5, no. 1 (2017): 51-66.

19 Ernest Renan, "What is a Nation," in Nation and Narration, ed. Homi K. Bhabha (London: Routledge, 1990), 19. 
grievances about selective commemoration that legitimise certain contemporary political projects or historical narratives are common in politically-charged settings. As Stephen Ellis suggested: "It is far better to find models of what they are or were, in other words to identify structures or ideas that have been central to the historical experience of these societies." ${ }^{20}$

Rebuilding a (post-conflict)-state to include communities in both northern and southern Somalia has proven a challenge from the moment of complete state collapse in $1991 .^{21}$ In light of contested political memories and historical group grievances, and since many Somalis have long been in a state of traumatic transition, a Somali-wide negotiated political settlement as part of a broader post-war recovery remains out of reach. Instead, stratified patterns of political memory connect past and present political realities in Somaliland. Protracted armed conflict over state power and resources between the military regime and its opponents since the late 1970s produced a legacy which compartmentalised Somalis, and even non-Somalis who study them, along clan lines. Somalis, as well as non-Somalis who write about them, often find a reason to debate the basic facts of the civil war, such as when hostilities began. ${ }^{22}$ Similar divisions are found when dealing with other conflict-ridden and post-conflict societies. But not only is it necessary to avoid the pitfall of propagating one clan's historical narratives as the preferential or official one, but also a just account demands that the political histories of an array of groups (or clans) be considered equally. In reviewing Lidwien Kapteijns' controversial book about the 1991 clan-based wars in Somalia, Ken Menkhaus finds that "[a]s in many other post-war settings, a critical dimension of historical grievance narratives is all about when one begins the story." He concluded: "Intentionally or not, Kapteijns' book provides one clan... much more ammunition in its grievance narrative than others, and

20 Stephen Ellis, "The Mutual Assimilation of Elites: The Development of Secret Societies in Twentieth Century Liberian Politics," in The Powerful Presence of the Past: Integration and Conflict along the Upper Guinea Coast, eds. Jacqueline Knörr and Wilson Trajano Filho (Leiden: Brill, 2010), 185.

21 "Move by Hassan Sheikh Unites Somaliland Tribes against Him," The Indian Ocean Newsletter, no. 1429 (17 June 2016).

22 See Ingiriis, “Many Somalia(s)," 348. Daniel Companon recalls his attempt to remain politically neutral during the armed conflict in Somalia in the 1990s: "I have been trying to keep a line that is not biased in favor of one clan. I was told by the former editor of Horn of Africa that my early article on the opposition fronts made many Northerners especially Isak [Isaaq] people very unhappy. I am proud of it because this allowed me to publish later an article (in Politique Africaine) explaining the secession of Somaliland as a legitimate process (although it was opposed by sections of the non-Isak clans in the North). In the long run, I retained some credibility.” Daniel Compagnon, email communication, 24 Jan 2014. 
for that reason [it] will be heavily contested." ${ }^{23}$ In order to better understand the nuanced historical trajectories of political memories and the state-building project in Somaliland, it is imperative to reflect on how these crucial themes relate to the political and cultural construction of historical group grievances in this context, and what connects certain groups to the past.

\section{Siad Barre and Somaliland}

The former British Protectorate of Somaliland joined the former Somalia Italiana (Italian Somalia) in 1960, the year of African Independence, to form the Somali Republic. ${ }^{24}$ The merger was initially conducted peacefully, but the subsequent dispensation of power - where both powerful positions of the Presidency and the Prime Minister's office went to southern politicians - angered Isaaq elites who had expected one of their own to assume the relatively powerful post of the Prime Minister. This dissatisfaction ultimately manifested in an aborted military coup led by relatively young Isaaq military officers in December $1961 .^{25}$ The aborted coup did not lead to a popular uprising, even when some were killed and others wounded, but its consequences added to the mosaic of Isaaq historical grievance in the long run on grounds of a coherent victimhood commemoration. An independent judicial process in a Mogadishu criminal court presided over by a British judge, Indian lawyers and Italian prosecutors acquitted the coup plotters. ${ }^{26}$ The desperate Isaaq political situation went hand-in-hand with growing socio-economic underdevelopment of the Isaaq region, as euphemistically expressed in a melancholic 1962 poem by one prominent Isaaq poet,

23 Ken Menkhaus, "Review: Clan Cleansing in Somalia: The Ruinous Legacy of 1991 by Lidwien Kapteijns. Philadelphia, PA: University of Pennsylvania Press, 2013,” The Journal of Modern African Studies 52, no. 2 (2014): 679-681.

24 Amina H. Adan, “Somalia: An Illusory Political Nation-State," South Asia Bulletin 14, no. 1 (1994): 99-109.

25 "Documentary - Taariikh Nololeedka Cabdilaahi Koongo Qaybtii 9aad," (between min. 00:21-04:53), accessed 26 August 2014, https://www.youtube.com/watch?v= 36e9oM9Or7Q; "Documentary - Taariikh Nololeedka Cabdilaahi Koongo Qaybtii 10aad," (between min. 00:31-08:43), accessed 26 August 2014, https://www.youtube.com/watch?v=EsANwfl CoYM; "Documentary - Taariikh Nololeedka Cabdilaahi Koongo Qaybtii 11aad," (between min. 00:28-09:22), accessed 26 August 2014, https://www.youtube.com/watch?v=-1s7DkF1T2E; and "Documentary - Taariikh Nololeedka Cabdilaahi Koongo Qaybtii 12aad," (between min. 00:28-09:57), accessed 26 August 2014, https://www.youtube.com/watch?v= pMNZSVWRF_c.

26 Ibid. 
"adduunyo Hal baan lahaa, Hashii horor baa la tagay, haan maran baan sidaa" (of all the world possessions, I had only but one She-camel and the She-camel was robbed by a beast, so I'm holding an empty vessel). ${ }^{27}$ Isaaq elites played a less important role in politics until the change in administration in July 1967. At that point, the post of Prime Minister went to Mohamed Haji Ibrahim Egaal, the Isaaq's most prominent politician. The elation of many Isaaq that one of their own had finally assumed the position of Prime Minister would last no more than two years and three months.

The successful military coup of October 1969, which followed a few days after the assassination of President Abdirashid Ali Sharmarke, interrupted Egaal's efforts to defuse Isaaq public grievances towards the government in Mogadishu. ${ }^{28}$ The first years of General Siad Barre's rule saw important achievements, including literacy campaigns, massive developmental projects, and improvements to health care and education. These achievements remain central for the memory and commemoration of the Siad Barre regime in southern Somalia. Indeed, at first, Siad Barre made crucial promises to repair the socio-political injustices and corrupt practices that had characterised the previous civilian administration. These promises proved empty, however, as he increasingly adopted clan-oriented policies, favouring one clan over the other to consolidate his power. ${ }^{29}$

The General's increasingly repressive measures gave rise to armed opposition movements - the Isaaq-dominated Somali National Movement (SNM) was founded in 1981 - and the emergence of these movements further fuelled the repression. Feeling threatened, Siad Barre, in the late 1980s, allowed his ground and air forces (including mercenaries from South Africa) to target civilians belonging to the clans from which the leaders of the armed insurgent movements hailed. In northeast Somalia (present-day Puntland), Siad Barre's army destroyed the powerbase of the armed opposition within a few years. However, in northern Somalia (present-day Somaliland), the situation was more dire and prolonged. ${ }^{30}$ The Isaaq's northern regions of Waqooyi Galbeed (Northwest) and much of Togdheer were hard hit by Siad Barre's forces during the armed

27 “Cali Sugulle iyo Heestii 'Hiddiidiiyooy Hidii (1962)," (between min. 0:01-7:31), accessed 28 April 2020, https://www.youtube.com/watch?v=QMFaFE-HDK8.

28 Mohamed Haji Ingiriis, "Who Assassinated the Somali President in October 1969 The Cold War, the Clan Connection or the Coup d'État," African Security 10, no. 1 (2017): 1-24.

29 "Pointers - Somalia: Siad Barre’s Foes," Africa Confidential; "Somalia: Somalia Barre Hangs on," Africa Confidential; and "Somalia: Generals on the Move," Africa Confidential.

30 Michael Simmons, "Thousands of Somalis Reported Dead in Genocide Attacks," The Manchester Guardian Weekly, 15 January 1989. 
struggle spearheaded by the SNM, which aimed to defeat and depose the military regime. ${ }^{31}$ The war between Siad Barre and the SNM intensified and climaxed in 1988 when Siad Barre enacted a supposedly peaceful accord with Colonel Mengistu Haile Mariam, his Ethiopian counterpart. The two dictators agreed to cease hostilities that were born out of the disputed Somali region in Ethiopia. They also promised to stop providing support to each other's armed opposition groups. ${ }^{32}$

The SNM established a temporary military base in Ethiopia's Somali region. Fearful of expulsion by Mengistu, the opposition group hastened to move to northern Somalia in what, from a military perspective, came close to suicide. ${ }^{33}$ This desperate military measure was conducted clandestinely. As soon as they crossed the border into Somalia, SNM forces began to storm Siad Barre's army in the two most populated Isaaq towns in the northern region, Hargeysa and Bur'o. Siad Barre's military authorities, anticipating that the agreement with Mengistu would bring about the SNM's demise, were caught by surprise. They had seriously underestimated that, as Michael Walls writes, the SNM "was formed with a strong sense of grievance that only grew more intense as Siad Barre's government became more brutal and repressive," leading to "consolidated Isaaq solidarity." ${ }^{34}$

The military regime's response to the surprise attacks was devastating. It unleashed a series of devastating campaigns on the Isaaq civilians, most of whom were seen as sympathetic to - and supportive of - the SNM struggle. The campaign further hardened clan divisions, with targeted civilians forced to seek

31 Confidential Cable: "Two Views on Somaliland: Hostile Forces Target Economy, No Return to a Unified Somalia.” This cable was sent from US Embassy in Djibouti to the State Department in Washington. Accessed 7 December 2014, http://cables.mrkva.eu/cable.php?id=118293. For the SNM, see Gérard Prunier, "A Candid View of the Somali National Movement," Horn of Africa 13-14, no. 3-4 \& no. 1-2 (1990): 107-120; Ibrahim Megag Samatar, "Light at the End of the Tunnel: Some Reflections on the Struggle of the Somali National Movement," in Mending Rips in the Sky: Options for Somali Communities in the 21st Century, eds. Hussein M. Adam and Richard Ford (Lawrenceville, N.J.: The Red Sea Press, 1997), 21-48; Said S. Samatar, "How to Run an SNM Gauntlet," Horn of Africa, 13, no. 1-2 (April \& June 1990): 78 - 87; and Michael Walls, "Liberation Struggle for Regime Change: Somaliland's Transition from Conflict to Civilian Government," in National Liberation Movements as Governments in Africa, ed. Redie Bereketeab (London: Routledge, 2017), 218-219.

32 "Somalia: Tango in the Ogaden," Africa Confidential, 27, 11, 21 May 1986, 4; "It is Impossible to Disdain People’s Memory, Mr President,” KAAH: A Periodical Journal of the Ogaden National Liberation Front 111 (July 1988): 15-17.

33 “Somali National Movement," (between min. 02:35-05:15), accessed 20 May 2014, http:// www.youtube.com/watch?v=XWosiLB6YNg.

34 Walls, "Liberation Struggle for Regime Change," 218. See also Jutta Bakonyi, "Moral Economies of Mass Violence: Somalia 1988-1991," Civil War 11, no. 4 (2009): 434-454. 
the protection of the SNM, no matter if they previously supported their cause. As a result, in the late 1980s much - if not almost all - human and material infrastructure of Waqooyi Galbeed (the Northwest) region was destroyed. Human rights reports warned that "a long-term human rights crisis" loomed amidst heavy "human rights abuses," even "civil war in the north," well before the armed conflict turned into full-blown civil war throughout Somalia. ${ }^{35}$ International observers writing for The Guardian and The Times of London bolstered the argument that the military regime aimed to obliterate the Isaaq clan as the era of Siad Barre was fading. ${ }^{36}$

Following heavy bombardment in May 1988 from both Somali levies and non-Somali mercenaries, the most important Isaaq town of Hargeysa came to resemble Beirut in the 1970s or Berlin in the 1940s. Somaliland elites also refer to Hargeysa as the "Dresden of Africa." The reference is indicative of their attempt to make the suffering legible to a foreign audience. Therefore, it does not primarily serve to commemorate the events in Somaliland itself but rather to legitimise the secession project abroad. During this period, the Isaaq population was turned into or, in the eyes of the military regime, made themselves "secondclass citizens in their own homeland," in the words of a former diplomat of the Siad Barre regime. ${ }^{37}$ As the armed conflict dragged on and intensified, most Isaaq civilians fled to the Ethiopian border to escape the military regime's war machines. ${ }^{38}$ Still, death and destruction awaited many on the road. Country reports documented that Siad Barre's forces used landmines "to threaten the ci-

35 Africa Watch, Human Rights Abuses and Civil War in the North: A Report from the U.S. General Accounting Office (New York: Africa Watch, 1989); Amnesty International, Somalia: A Long-Term Human Rights Crisis (New York: Amnesty International, 1988); and Amnesty International, Somalia: Imprisonment of Members of the Isaaq Clan Since Mid-1988 (New York: Amnesty International, 1988). On the geographies of the genocide and the magnitude of the crisis, see Mohamed Haji Ingiriis, “'We Swallowed the State as the State Swallowed Us': The Genesis and Genealogies of Genocide in Somalia," African Security 9, no. 3 (2016): 237-258; and Sarah G. Philips, "Proximities of Violence: Civil Order Beyond Governance Institutions," International Studies Quarterly 63, no. 3 (2019): $680-691$.

36 "Somali Military Bid to Obliterate Clan as Barre Era Fades," The Times, 2 July 1987; and "Somali Troops in "Massacres and Bombings," The Guardian, 24 June 1988. See also "Somalia: Civilians Massacred," The Indian Ocean Newsletter, no. 321 (27 February 1988), 4; and "Somalia: Thousands Dead,” The Indian Ocean Newsletter, no. 340 (9 July 1988), 1.

37 Abdullahi Dool, "Good Governance: Self-Administering Regions within a Democratic Union,” Somalia 4 (June 2001): 9. See also "Somalia: The Forgotten Men,” New African, April 1988.

38 Africa Watch, A Government at War with Its Own People: Testimonies About the Killings and the Conflict in the North (New York: Africa Watch, 1990). 
vilian population and protect military installations." 39 The heavy-handed military pressure imposed on the Isaaq brought about a proliferation of armed resistance movements as other clans became convinced that the only way to depose of the military regime would be by way of a violent takeover. ${ }^{40}$

The legacy of this war remains one of trauma for the Isaaq population. It also resulted in the commemoration of the "sacred" separation of Somaliland from Somalia. The eventual fall of Siad Barre enabled Isaaq political players to recreate the colonial border that demarcated what used to be British Somaliland and Italian Somalia. They initially argued not for separation, but for the "restoration of sovereignty lost in the 1960 merger with Somalia." ${ }^{41}$ They further used claims of abuses of power, the autocratic exploitation of state resources, and the military regime's policy of targeting Isaaq civilians during the period of armed insurgency as the driving force behind this push for separation. Nowhere was this more plainly emphasised than in the June 1996 paper of the Somaliland government that sought official recognition of Somaliland. That explicitly connected separation with the political memory of the Isaaq people. The paper is replete with a selective historical narrative of genocide, massacre and torture. $^{42}$

In recent years, a more detailed and nuanced picture of Siad Barre's regime has been presented in order to understand the causes and consequences of what has been called a genocidal campaign by Isaaq leaders as well as foreign observ-

39 Megan Wertz, "Country Profile: Somaliland," Journal of Conventional Weapons Destruction 10, no. 1 (2006): 38. See also Robert Gersony, Why Somalis Flee: Synthesis of Accounts of Conflict Experience in Northern Somalia by Somali Refugees, Displaced Persons and Others (Washington: State Department, 1989); Robert Gersony, "Why Somalis Flee: Conflict in Northern Somalia," Cultural Survival Quarterly 13, no. 4 (1989): 45-58; and "Thousands Flee as Somali Soldiers Massacre Civilians," The Observer, 3 July 1988.

40 For discussion of the formation of armed opposition movements, see Daniel Compagnon, "Somali Armed Movements: The Interplay of Political Entrepreneurship and Clan-Based Factions," African Guerrillas, ed. Christopher Clapham (Oxford: James Currey, 1998), 73-89; Daniel Compagnon, "The Somali Opposition Fronts: Some Comments and Questions," Horn of Africa 13, no. 1-2 (January-June 1990), 29-54; Daniel Compagnon, "Dynamiques de Mobilisation, Dissidence Armée et Rébellion Populaire: Le Cas du Mouvement National Somali (1981-1990)," Africa 47, no. 4 (1992): 502-530; Marcel Djama, "Sur la Violence in Somalie: Genése et Dynamique des Formations Armées,” Politique Africaine 47 (1992): 147-152; Mohamed Haji Ingiriis, "Between the Devil and the Deep Blue Sea: The Birth and the Breakdown of the Somali Armed Movements, 1976-1999," in National Liberation Movements as Governments in Africa, ed. Redie Bereketeab (London: Routledge, 2017), 233-248; and Walls, "Liberation Struggle for Regime Change.”

41 Field interviews and observations in Hargeysa, April-May 2018.

42 The Republic of Somaliland, Submission on Statehood and Recognition of Republic of Somaliland, Hargeisa, June 1996. 
ers. ${ }^{43}$ Through a lens of clan versus clan tension, military regime authorities sought to destroy the SNM by targeting Isaaq civilians who shared clan affiliation with armed opposition movements. The presence of a single dominant clan at the top of the military regime helped political players from other clans to rally their supporters to revolt. ${ }^{44}$ Since it sanctioned state-sponsored violence, the Siad Barre state - unlike, for instance, the Sierra Leonean state $e^{45}$ - became a significant point of contention for different clans. After Siad Barre was overthrown, clans who benefitted from his regime refused to accept that they were no longer in control, while those clans oppressed by his military regime could not be convinced to share power with those who had been friendly towards the state. ${ }^{46}$ Over time the conflict escalated from disputes about the distribution of state spoils to one pertaining to its survival as a single entity. As human rights organisations described, this was a complete transformation of the nature of violence. ${ }^{47}$ The political memory sustaining the Somaliland separation traces its roots to what the Isaaq elites remember as the "Hargeysa Holocaust" perpetrated against them in 1988 by the military regime, ${ }^{48}$ though this portrayal is not shared in the south. Somali President Farmaajo, for example, uses the term "atrocities" to describe the event.

Amidst the geopolitics of the Cold War, Siad Barre acted with impunity as a "gate-keeper" between the West and the East, initially allying for eight years with the Soviets and then switching sides to join the United States. The years during which his regime allied with the West were the most brutal of his rule. ${ }^{49}$ The re-

43 Ingiriis, The Suicidal State in Somalia; Ingiriis, “"We Swallowed the State”; Ingiriis, "How Somalia Works"; Ingiriis, "Between the Devil and the Deep Blue Sea”; and Ingiriis, "State Violence and Clan Violence."

44 Ingiriis, The Suicidal State in Somalia, 194. See also Pierre Englebert, Africa: Unity, Sovereignty \& Sorrow (Boulder: Lynne Rienner Publishers, 2009), 23.

45 David Keen, Conflict \& Collision in Sierra Leone (Oxford: James Currey, 2005), 105.

46 Field interviews and observations in Hargeysa, July-August 2016.

47 Africa Watch, A Government at War with Its Own People; Africa Watch, Human Rights Abuses; Amnesty International, Somalia; and Amnesty International, Somalia. For additional analysis, see Daniel Compagnon, "State-sponsored Violence and Conflict under Mahamed Siyad Barre: The Emergence of Path Dependent Patterns of Violence," World Peace Foundation Occasional Papers, 22 October 2013, accessed 23 December 2013, http://sites.tufts.edu/reinventingpeace/ 2013/10/22/state-sponsored-violence-and-conflict-under-mahamed-siyad-barre-the-emergenceof-path-dependent-patterns-of-violence/.

48 Ingiriis, “'We Swallowed the State.”

49 Box 4, folder "Somalia - President Mohammed Siad Barre" of the National Security Adviser's Presidential Correspondence with Foreign Leaders Collection, Gerald R. Ford Presidential Library. For an interesting analysis on the US-Siad Barre relationship, see Mohamed Diriye Abdullahi, "In the Name of the Cold War: How the West Aided and Abetted the Barre Dictatorship 
gime received massive military aid, which fuelled and prolonged the armed conflict and introduced the automatic modern weaponry that still remains in use in Somalia today. Some Siad Barre military officers confirmed to American authorities in Mogadishu that their forces, as well as their "allies," used US military equipment to break the Isaaq powerbase during the brutal campaigns against that community. ${ }^{50}$ The "allies" were local non-Isaaq clan militia in the North fighting on behalf of the Siad Barre military regime.

State policy declared that to survive in the pool of dissenting armed opposition movements that emerged from the 1970s, the military regime worked under a system of patronage and patrimonialism to reward one clan and punish another, with the assistance of other allied clans. Officers of the military regime were also ordered to execute members of clans that opposed Siad Barre. ${ }^{51}$ In the southern regions, this only affected people temporarily but in the northern regions, punishing the communities from which armed opposition groups hailed was an extensive process because local civilians assisted their youth joining the insurgency. ${ }^{52}$

An over-reliance on clan punishment caused clans not only to fight for the spoils of the state to compensate for the military regime's brutality but also to exact revenge on each other. Refugees from the Somali region in Ethiopia were for this reason targeted during the 1991 clan-based wars. Local communities targeted them in retribution for contributing to the regime-sponsored campaigns of punishment against the local clans in the south in the 1980s. ${ }^{53}$ The Siad Barre regime also targeted the Somali Patriotic Movement (SPM), an Ogaadeen-dominated armed resistance group in Kismaayo, Jubada Hoose (Lower Juba), and the United Somali Congress (USC), a Hawiye-dominated armed resistance group in the country's central and southern regions as well as Mogadishu. The collective clan punishment campaigns asserted through brutal military measures eventually led to the collapse of the military regime in January 1991, set the stage for the 1991 clan-based wars after Siad Barre's fall and

of Somalia," in Genocide, War Crimes \& The West: History and Complicity, ed. Adam Jones (London: Zed Books, 2004), 241-259.

50 Cable from US Embassy in Mogadishu to Washington, "Sub: Peace Breaking Out in the North?,” accessed 31 August 2014, https://wikileaks.org/cable/1990/03/90MOGADISHU2527.html. 51 Ibid.

52 Interview with S. A. A., Gebiley, 28 November 2019.

53 “Somalia: The Ogadeni’s Misfortune," Africa Confidential 25, no. 21 (1984): 5-7. See also Keydmedia, "Baladweyne: Qaxootigii Ogaadeenka oo Ciidam[a]da Maxamad Siyaad Barre ay Hubeeyeen!,” (between min. 00:25-05:13), accessed 26 July 2014, http://www.youtube.com/ watch?v=Dt1pqsZ2R-I. 
flight, and culminated in heated historical grievances held by each Somali clan as political memory in its own right. ${ }^{54}$

\section{Political Memory and Construction of Identity}

After the fall of the Siad Barre regime, SNM leaders in May 1991 convened a conference at which representatives of clans from the northern regions proclaimed an independent Somaliland state. The subsequent separatist state-building project to come would not prove an easy task, however, with years of internecine fighting between sub-clans of the Isaaq following the declaration. Some supported the separation and others opposed it until the mid-1990s, when a relative peace was achieved with grand conferences in the towns of Borame and Sheikh.

Beyond the region, Isaaq in the diaspora who witnessed the war first-hand also carried the scars inflicted by the Siad Barre regime and wartime atrocities. Somaliland's declared separation thus garnered considerable moral and financial contribution from many diasporic Isaaq communities traumatised by the protracted and bitter armed struggle. The Isaaq diaspora mobilised the issues of political marginalisation, economic exclusion and genocidal campaigns perpetuated by Siad Barre's regime to engender a sense of unity, which made reaching consensus locally easier than in southern Somalia. Even when Somaliland encountered a torturous conflict within the clan, the Isaaq diasporic communities invested significant energy and resources to resolve local disputes and ensure separatism. ${ }^{55}$

The immediacy with which Isaaq elites proclaimed independence for the Somaliland state after the fall of the military regime testifies to how Siad Barre's regime was seen as central to the practice of political memory. In conversations on the streets of Hargeysa, many Isaaq men and women in their everyday engagement with the Somaliland question evoke the scorched-earth campaigns committed by the Siad Barre regime to promote the case for international recognition for their separatist state. ${ }^{56}$ As Compagnon aptly observed in the early 1990s, "L'attitude de la population [I]saaq trouve son fondement dans la guerre civile qui débuta dans le Nord avec la lutte armée" (the attitude of the Isaaq population is rooted in the civil war that began in the North with the armed strug-

54 Ingiriis, The Suicidal State in Somalia.

55 Stephanie R. Bjork, Somalis Abroad: Clan and Everyday Life in Finland (Chicago: University of Illinois Press, 2017), 109.

56 Field observations, Hargeysa, 26 July 2016. 
gle). ${ }^{57}$ The colonial and post-colonial outlook of the Isaaq today stands markedly apart from the traditional Somali nation-state conception based on one unified greater Somalia statehood comprising all five Somali zones in the Horn of Africa.

Every year, many Isaaq gather in Somaliland towns and in cities like London and Nairobi to commemorate 18 May 1991, the day when Somaliland independence was declared. In these commemoration ceremonies, the Isaaq people, whether in the diaspora or back home, assert pride, most notably with regard to Somaliland's relative stability in contrast to the continued violent character of politics in southern Somalia. There, the pretence of an "armed peace" protected variously by Ethiopian, Kenyan or other African forces predominates, while in Somaliland the practice of an "unarmed peace" unaccompanied by physical foreign presence prevails. The contrast is the main reason, apart from clan sentiments, why in southern Somalia people still refer to Siad Barre's maintenance of relative calm until the civil war reached the capital in Mogadishu in December 1990 as xilligii nabadda (the peaceful era). As one Isaaq female intellectual in Hargeysa pointed out, "their [southern Somalia's] glorious days are our nightmare. For example, they think Siad Barre was their saviour when he was our destructor." ${ }^{58}$ Both Radio Mogadishu and the Somali National Television eulogise the era of the military regime by replaying interviews and programmes released while Siad Barre was in power. ${ }^{59}$ Overall, people in southern Somalia and even elsewhere in Puntland recall Siad Barre and his regime in ways distinctly different to those in Somaliland.

A number of episodes at the intersection of politics and commemoration reinforced divisions between Somaliland and southern Somalia. For example, Hassan Sheikh Mohamud, who led southern Somalia from 2012 to 2017, organised a state burial for General Mohamed Ali Samatar, who served as Siad Barre's Vice President, Prime Minister and Minister of Defence. As the Journal of the AngloSomali Society reported in 2016, Samatar, in a US civil court, "admitted his responsibility for torture, extrajudicial killing, war crimes and other human rights abuses committed against the civilian population during the brutal military dic-

57 Author's translation. Daniel Compagnon, 'Somaliland, un Ondre Politique en Gestation?', Politique Africaine 50 (June 1993): 10.

58 Interview with S.C.A., Hargeysa, 4 May 2018.

59 Radio Muqdisho, "21 Oct.Taariikhdii kacaanka iyo khudbadihi ugu muhiimsana Madaxweyne Siyaad. Keydka R/muqdisho.DHAGEYSO,” accessed 9 September 2018, https://www.ra diomuqdisho.net/21-oct-taariikhdii-kacaanka-iyo-khudbadihi-ugu-muhiimsana-madaxweynesiyaad-keydka-rmuqdisho-dhageyso/. 
tatorship of the Siad Barre régime."60 The (s)election of Mohamed Abdullahi Mohamed 'Farmaajo' to succeed Hassan Sheikh Mohamud as President in Mogadishu through a parliamentary vote on 8 February 2017 also opened old wounds for the Isaaq. Many regarded Farmaajo as part of Siad Barre's regime, in which Farmaajo served as a junior staff member at the Somali Embassy in the United States before defecting to apply for political asylum in America in the late 1980s. Farmaajo's government further triggered this notion of a connection between Farmaajo and Siad Barre when it added the latter's son-in-law to a committee tasked with mediating between the federal government in Mogadishu and leaders in Somaliland. Speaking at the commemoration of Women's Day on 8 March 2018, Somaliland President Muuse Biihi reminded Farmaajo of how "his uncle (Siad Barre) destroyed lives and wealth" in the North. ${ }^{61}$ With an emotional speech in which he seemed to shed tears, Biihi's words caused elderly women in his audience to cry out in support. Around that time, at King's Café in Hargeysa, a businesswoman assessed Farmaajo's performance as President after a year in office and reached the same conclusion as Muuse Biihi: "Farmaajo is doing nothing other than imitating his uncle [Siad Barre]."62 No matter if we assume that the displayed emotions are completely genuine, or at least partially political theatre, it is clear that people make sense of their position by drawing from historical grievances that reverberate in the present. In this case, "never a predatory state again" serves as a code echoing political memories that caution against any oppressive rule or reproduction of Siad Barre's later reign. ${ }^{63}$

Commemorations such as these in southern Somalia impede fruitful discussions of how the entire territory might come together as one unified, non-violent nation-state. As renowned historian of Somali society Charles Geshekter noted, it was - conceptually speaking - the Isaaq masses who comprehended that "the railroad train of Somali history had gone around a steep bend in the tracks in 1991, striving the past decades to feed and sustain their administrative state apparatus, while leaving the identification of its historical roots to academics."64

60 “General Mohamed Ali Samatar, 1931-2016," Journal of the Anglo-Somali Society 60 (Autumn 2016): 62.

61 "Madaxweyne Muuse Biixi oo dumar ka ooy siiyay + xuska 8march," Hadhwanaag News, March 8, 2018; and "Khudbad Muuse Biixi Cabdi," Somaliland Television, 8 March 2018.

62 Interview with S.A.H., Hargeysa, 29 April 2018.

63 Field interviews, Hargeysa, July-August 2016 and April-May 2018.

64 Charles Geshekter, email communication, 24 April 2013; See also Lee Cassanelli, "Reconciliation and Reconstruction: Are there Lessons from Somalia’s [R]ecent History?,” paper present- 
This does not mean that political memory in Somaliland is more legitimate or powerful than in southern Somalia. Rather, it highlights that in the Somaliland case charged political memory supported the cause of political expediency. Each post-Siad Barre government in Somalia developed a special website mainly for propaganda purposes, that is to advance its political project. But none could present a similarly coherent, albeit selective and self-centred, case of historical grievance as that of Somaliland. ${ }^{65}$

Southern Somalia's inability to present an equally (excessively) orderly national myth apparently discourages people in Somaliland from the belief that reuniting with southern Somalis would result in improvement for them. ${ }^{66}$ But shifting clan alliances and changing local political conflicts in Somaliland also create conditions for the Isaaq people to re-assess the benefits of separatism without discarding the politics of memory altogether. Whenever a case of genocide denial arises from southern Somalia, both pro-separatist and anti-separatist Isaaq camps take on defensive positions in relation to how Somaliland has or has not principally been subjected to gumaad (genocide). ${ }^{67}$

In Hargeysa, the cause of separatism is also present in commemorative practices, such as memorials. A monument celebrating Daljirka Dahsoon (the Unknown Soldier) in Hargeysa starkly contrasts with Mogadishu's tribute to Daljirka Dahsoon. The latter embodies the unified state in southern Somalia, while the former stands for the separate state in Somaliland. Hargeysa's Daljirka Dahsoon evokes a common, grievance-based historical memory of war trauma. It stands in Kheyriyadda, the city centre of Hargeysa, a monument depicting a MiG17 war aircraft with a Somali national flag on both sides. This epitomises Siad Barre's warplanes that launched airstrikes on the town while flying from the Hargeysa airport in $1988 .^{68}$ The base, symbolising the bombardment, is decorated with representations of the civilians massacred by the military regime, such as a mother carrying her son on her back covered with a waving Somaliland flag. Other drawings show an old man who lost both hands and one leg at the height of the military regime's punitive campaign of an aerial attack on the Isaaq. ${ }^{69}$ The

ed at the $6^{\text {th }}$ International Congress of Somali Studies, Berlin, 6-9 December 1996; and Simon Horner, “Somalia: Can the Jigsaw be Pieced Together," ACP-EU Courier 162 (1997): 46-53.

65 Mohamed Haji Ingiriis, "From Pre-Colonial Past to the Post-Colonial Present: The Contemporary Clan-Based Configurations of Statebuilding in Somalia," African Studies Review 61, no. 2 (2018): 55-77.

66 Field interviews, Hargeysa, July-August 2016 and April-May 2018.

67 Field interviews, Hargeysa, November-December 2019.

68 Field observations, Hargeysa, 11 July 2016 and 29 April 2018.

69 Ibid. 
monument displays its message with the phrase: Xus oo Xusuusnow (Respect and Remember). Monuments of this nature have mushroomed in Hargeysa. They can be seen starting from the entrance of the Egaal International Airport and continuing to a depiction of an armoured tank in the city centre that serves as yet another illustration of how political memory is present on public display. Monuments such as these are used as backdrops for public events, and in particular for the celebration of Somaliland independence day on May 18. Julie MacArthur noted a similar proliferation in her study of late colonial Kenya, highlighting that "public monuments scattered throughout the capital depict an upheld hand gripping the mapped geo-body of Somaliland."70

Craving for a separate state is so strong among the Isaaq that political players from the community as well as the northern public use terms such as the "Somali Territories" and "Somali-speaking peoples" to refer to the region and the people living therein. ${ }^{71}$ This is not only to avoid any mention of Somalia but also to emphasise the position of Somaliland within the wider Somali states of the Horn. After many years of conflict and negotiations between the Isaaq and the non-Isaaq as well as within the Isaaq, the independence project through grievance-based political memory continues to divide the clans living in Somaliland. For instance, people opposed to separation have charted a new form of identity as "unionists" opposing the "secessionist one clan enclave."72 Their critics brand them "enemies of the state."73

A military schism also divides people into mujaahid (holy warrior: plural mujaahidiin) and non-mujaahid. Mujaahidiin are, broadly, those who were part of the SNM struggle. The title of mujaahid is specially reserved for military leaders such as Muuse Biihi Abdi, the current President of Somaliland, and his close friend Mohamed Kaahin, the Minister of Interior, both former commanders of the now defunct SNM. The mujaahid versus non-mujaahid dichotomy sows suspicion among the clans and compounds the alienation of those who are not Isaaq because they did not belong to the SNM. The divide between those who were $\mathrm{mu}$ jaahidiin and those who were not appears to have been lastingly defined during the armed SNM struggle against the military regime. ${ }^{74}$ Both grievance-based po-

70 Julie MacArthur, Cartography and the Political Imagination: Mapping Community in Colonial Kenya (Athens, OH: Ohio University Press, 2016), 229.

71 Ingiriis, "From Pre-Colonial Past to the Post-Colonial Present."

72 Field interviews, Hargeysa, July-August 2016 and April-May 2018.

73 Ibid.

74 For the foreseeable future, Somaliland seems to be politically controlled by Muuse Biihi's powerful clan of the Sa'ad Muuse/Habar Awal of the Isaaq, which will likely compound rising 
litical memory and historical commemoration practices in Somaliland contribute to legitimising separatism. However, the ways in which people have manipulated the narratives of the horrors of Siad Barre's rule and the heroic struggle of the SNM mujaahidiin also leads to a number of critical challenges, as outlined in the next section.

\section{Challenges to Grievance-Based Separatism}

The post-conflict Somaliland state faces internal challenges of nation-building. A major obstacle is that an overarching national identity encompassing of all the clans and communities in Somaliland was not born out of the formation of the separatist state. The conflict over the Isaaq past versus non-Isaaq past still stands. On one hand, despite the developing visions of one united Isaaq political memory as a result of the "defection" of some of Somaliland's political players to Mogadishu, Somaliland authorities are striving to strengthen Isaaq unity by repeatedly bringing up the genocide and the success of the SNM in liberating their people from brutal oppression..$^{75}$ On the other hand, while reinforcing the importance of the SNM's achievement, the Isaaq-dominated Somaliland authorities are wary of sanctioning a historical narrative that elevates one clan. They worry that non-Isaaq clans may feel excluded and complain of further political marginalisation by the Somaliland separatism if the SNM political memory is made the only official one. Compared with previous years, historical narratives of the non-Isaaq can increasingly be observed in the public celebrations and gatherings in Somaliland. Most Isaaq officials and intellectuals who delivered speeches in the first Laas Aanood Book Fair held in the heart of the Dhulbahante territory publicly acknowledged the political memory of the anti-colonial Dervish struggle (1899-1920), which non-Isaaq clans like the Dhulbahante frequently glorify in public discourses. Both Dhulbahante political players and their public use this history as a historical counterweight to the more recent, privileged Isaaq historical position. ${ }^{76}$

Distinct from the overwhelming majority of the Isaaq who desire separation from the south, most of the other clans living in Somaliland, such as the Dhulbahante, the Warsangeli, the Gadabiirsi and the lise clans, continue to contend that they are not supportive of Somaliland. Diasporic groups growing out of

local political tensions by reinforcing the alienation of large numbers of the Isaaq, especially the Habar Yoonis.

75 Field interviews, Hargeysa, November-December 2019.

76 Field interviews, Laas Aanood, 10-11 December 2019. 
these clans constantly urge their local political players to establish their own clan-states. ${ }^{77}$ Thus, whilst the process of state-building was largely successful in the Isaaq-dominated areas in Somaliland, prominent voices among the Dhulbahante in eastern Somaliland and the Gadabiirsi in western Somaliland continue to object to the separatist project. ${ }^{78}$ Many influential political players and military officials of these two clans supported the Siad Barre regime in the 1980s, although several others sided with the Isaaq and joined the SNM. Some Isaaq recall when the Siad Barre regime employed Dhulbahante and Gadabiirsi militias to counter the SNM attacks, but most largely refrain from publicly expressing this grievance to avoid inflaming relations with the non-Isaaq living within the Somaliland state. ${ }^{79}$ Some Gadabiirsi recall incidents in which the SNM allegedly took revenge on their community in the Awdal region in $1991 .^{80}$ Dhulbahante leaders' opposition to the Somaliland separation mainly stems from the common clan genealogy they share with Siad Barre. They also have a different memory of his regime in which they had enjoyed a significant share of the state's spoils, which causes them to wait for power to be taken by another Siad Barre. ${ }^{81}$

The (re)creation of national identity in Somaliland defined - and was itself defined by - the political memory aimed at crafting a new identity amongst those living in the region. However, not only is there no common identity to unite the Isaaq and the non-Isaaq, the Isaaq themselves are absent an allembracing unified clan ideology to advocate for Somaliland as a nation-state parallel to Eritrea or South Sudan. ${ }^{82}$ In Hargeysa, for instance, Isaaq sub-clans have separate quarters and one frequently hears "daantaas waxaa deggan reer hebel" (that quarter is populated by that clan). According to conventional clan wisdom, Hargeysa, the capital, is essentially divided into two quarters between

77 For discussion of rising separatism around the world, see Tanisha M. Fazal, "Go your Own Way: Why Rising Separatism Might Lead to More Conflict,” Foreign Affairs (July-August 2018): $113-123$.

78 Field interviews, Laas Aanood, 10-11 December 2019 and Boorame, 10-11 August 2016. 79 Field interviews, Hargeysa, July-August 2016 and April-May 2018.

80 "Sh. Xasan Daheeye oo ka sheekaynaya xasuuqii SNM ka samaysay Boorama," (between min. 0:01-11:23), accessed 13 September 2018, https://www.youtube.com/watch?v=_iNyr28420. Compare Arabsiyo News, 'Xasuuqii ka dhacay Arabsiyo xiligii taliska Siyaad Bare,' accessed 11 December 2017, https://www.youtube.com/watch?v=LB3K0UjoCK0. Northern and southern Somalians have two slightly dissimilar pronunciations of this clan. In the former, it is known as Gadabuursi while in the latter, it is referred to as Gadabiirsi. Since I am a southern Somali, I adopt the southern Somali pronunciation.

81 Field interviews, Laas Aanood, 10 - 11 December 2019.

82 Field interviews, Hargeysa, July-August 2016 and April-May 2018. 
the two main Isaaq sub-clans: Daanta Sacad Muuse (the Sa'ad Muuse Quarter) and Daanta Garhajis (the Garhajis Quarter). This division has emerged in spite of the fact that other Isaaq clans such as Arap also claim partial ownership of Hargeysa. ${ }^{83}$ Beyond the capital, regions populated by non-Isaaq are called darafyada (peripheries), reflecting how they are removed from the centre and trail the Isaaq areas in terms of power and resources. People from these peripheral regions, such as Sool and parts of Sanaag and Togdheer, take two routes to challenge Isaaq power: first, by seeking to align with other entities such as Puntland and second, by attempting to form their own mini states. ${ }^{84}$ Both strategies seek to weaken the Somaliland separatist project and force negotiations that will drive resources to these marginalised regions.

Prominent political players among the Gadabiirsi clan evince some support for Somaliland separation. ${ }^{85}$ In contrast with the Dhulbahante and the Warsangeli as sub-clans of the Harti, Gadabiirsi leaders integrated deeply into the Somaliland state system soon after factions of Dhulbahante and Warsangeli elders joined their Harti co-clansmen in Puntland in $1998 .^{86}$ The Gadabiirsi then operated separately from the Harti clan coalition that was formed to promote parochial clan interests contrary to their political alliance in the 1960s under the

83 Field interviews, Habaasweyn, 13 December 2019.

84 Field interviews, Laas Aanood, 10-11 December 2019.

85 Field interviews and observations, Boorame and Hargeysa, July-August 2016.

86 Gadabiirsi academic turned political player Ahmed Samatar once condemned what he called the clan domination of every aspect of life in Somaliland (a euphemism for the Isaaq), including the state system. That he now avidly supports Somaliland suggests that authorities in Hargeysa have accommodated some dissident voices like Samatar and Ali Khaliif Galayr, a senior Dhulbahante political player, thus achieving much greater political clout than they had possessed from the outset. See: "Prof. Ahmed Ismail [S]amatar (Somaliland waa muqadas) oo ka soo laabtey Hargaysa," (between min. 0:51-35:05), accessed 20 July 2016, https://www.youtube.com/ watch?v=cSfjo8KPZCU. Compare Samatar's earlier position: "Lewis's interpretations are curiously partisan. Here, for example, Siyaad Barre is excoriated for his dictatorial appetite, while Mohamed Ibrahim Egal, known across the Somali territory for his unmatched malfeasance and animus towards anyone more educated or competent, is handled with a soft touch, if not outright affirmation (284 [sic]). In addition, Lewis is so sold on the 'Somaliland' project that he maligns those Northerners who continue to hold on to their nationalist credo as cohorts driven by selfinterest. On the other hand, chauvinistic regionalists bent on dismembering the Somali Republic are portrayed as honourable, and with the right cause to boot. But it was not always like this in Lewis's work. Well into Siyaad Barre's rule, Lewis produced essays that celebrated the new order and what he thought it portended. What is one to make of these drastically shifting optics." Ahmed I. Samatar, "I. M. Lewis, A Modern History of the Somali: Nation and State in the Horn of Africa. Athens: Ohio University Press, 2002,” H-Net Reviews, December 2013, 2 accessed 27 December 2016, https://www.h-net.org/reviews/showpdf.php?id=8552. 
United Somali Party (USP). The primary concern for the Gadabiirsi population in the Awdal region has been to increase their parliamentary seat numbers, insofar as the comparatively few number allocated to them two decades ago limits their influence. ${ }^{87}$ The Iise and other peripheral clans like Fiqishinni/Eyr/Habar Gidir either supported or stayed silent on the issue of the SNM struggle.

When the SNM liberated most of Somaliland in February 1991, the organisation chose not to take advantage of the weaker position of the dissenting clans such as the Dhulbahante, Gadabiirsi and Warsangeli by conquering them and forcefully imposing SNM rule. This was partly because various Isaaq political players were focused on competing for power within that clan. With the eventual mediation of Isaaq clan elders who became part of a "hybrid" state system that could accommodate clan tradition and a modern state system, Somaliland came to enjoy a relative peace unknown to southern Somalia in recent years. ${ }^{88}$ Persistent peace lessened the possibility that Isaaq political players could resort to violent politics in achieving their ambitions.

However, the unequal power structure between those who hold the power and resources and those who do not created stratifications by clan and by class that invigorated new grievances within the Isaaq. This was demonstrated by the political fissures caused by the new Jeegaan alliance of two Isaaq subclans, Habar Awal and Habar Je'lo, in the presidential elections. As a result two other Isaaq sub-clans, Habar Yoonis and Edagalle (combined as Garhajis), have been comparatively marginalised. ${ }^{89}$ This attests to the fact that historical political memory can eventually be challenged by a political present in which the many intermittent conflicts between and within Isaaq clans predominate. ${ }^{90}$

Some Isaaq intellectuals are beginning to challenge the use of memories of a violent past as the kind of commemoration worthy of upholding separation from the south. For example, during a 2018 interview in Hargeysa, a university lecturer who spoke English with a Kenyan accent after living there for many years insisted that "the past is the past, let's talk to the present and turn to the future. It's wrong to stick to the past. Who is now killing who in Somalia? Monuments

87 Field interviews and observations, Boorame, 10-11 August 2016.

88 Field interviews, Hargeysa, April-May 2018.

89 Field interviews, Hargeysa, July-August 2016; and "Qaab-Dhismeedka Ciidanka Qaranka Somaliland, Hogaamada ciidanka iyo beelaha ay ka soo jeedaan,” September 2016.

90 Lughaya, 'Daawo Xukuumada Somaliland Oo Ka Hadashay Dagaal Khasaaro Gaystay Oo ka Soo Cusboonaaday Ceel-af-wayn', accessed 9 September 2018, http://www.lughaya.com/home/2018/07/24/ daawo-xukuumada-somaliland-oo-ka-hadashay-dagaal-khasaaro-gaystay-oo-ka-soo-cusboonaadayceel-af-wayn/. 
are wrong to display here."91 Even though the Isaaq grievance-based political memory has long served as the basic justification for Somaliland's separation, local Hargeysa people have already begun to position the military regime differently due to the longevity of the fragmentation along clan lines within Somaliland.

Commemoration of the military regime's oppressive rule follows two distinct trajectories. While some recall the regime with fondness (mostly the Garhajis), others (such as the Habar Awal and some Habar Je'lo) remember this time with bitterness. One Habar Yoonis female cook at a university guesthouse in Hargeysa lamented that, when Siad Barre was in power, the current fragmentation of the Somali state into weak mini-states was never possible. ${ }^{92}$ Other people, including some Edagalle elders, contend that Siad Barre's legacies will not soon be forgotten in Somaliland, in spite of anecdotal signs of nostalgia for the days of a unified Somalia. ${ }^{93}$ Some young people are beginning to hesitate when it comes to taking positions for either Somalia or Somaliland. This is not entirely surprising, because as times passes, an increasing percentage of the Isaaq population was not yet born when the worst atrocities took place in the late 1980s. People discuss the heated issues of political memory and take sides about the past, but although those who desire separation are still much more numerous than those who prefer the return to southern Somalia, people are beginning to reassess the separation stance. ${ }^{94}$

Although many Isaaq youth have no memory of a unified Somalia, prominent voices among Somaliland youth call for "reunion" with Somalia. ${ }^{95}$ Yet authorities in Hargeysa appear to ignore these emerging voices that would embrace either another merger with Somalia or the notion of recreating from Hargeysa a re-unified single Somali nation-state, with the capital relocated from Mogadishu to Hargeysa. More worryingly, authorities continue to suppress the voices of those who prefer unity with southern Somalia rather than Somaliland separation. ${ }^{96}$ This occurred when a young Isaaq woman went to Mogadishu in 2016,

91 Conversations with A.F.C., Hargeysa, 2 May 2018.

92 Conversation with F.H.S., Hargeysa, 22 July 2016.

93 Field interviews, Hargeysa, November-December 2019.

94 Field interviews and observations in Hargeysa, July-August 2016.

95 “Gabdho Reer Hargaysa ah oo Amaan Kala Dul dhacay Muqdisho Iyo Somali Weyn,” Cagaaran, accessed 11 December 2017, https://www.youtube.com/watch?v=Her3UPmpJ-s; "Gabadh re[er] Hargaysa oo Somaali Jacayl la ilmaysay,” Daljire, accessed 11 December 2017 https:// www.youtube.com/watch?v=4-QUNrBeaOI\&feature=youtu.be; and "Gabadh re[er] Burco ah oo Jawab Kulul siisay Islantii Farmaajo werartay,” accessed 11 December 2017, Daljire, https:// www.youtube.com/watch?v=0ID7RAD553s..

96 Field interviews, Hargeysa, July-August 2016 and April-May 2018. 
condemned the separatist Somaliland state while commending the Siad Barre regime, and was arrested in 2018. ${ }^{97}$ In July that year, an elderly Isaaq man living in the United Kingdom received threatening comments from other Isaaq after he recorded and posted on YouTube a video in which he praised Siad Barre. The man recounted the former president's childhood "bravery" as well as the leader's family history characterised by an ability to survive against all odds. He denounced the SNM struggle and contended that SNM fighters were conspirators working for Ethiopia. ${ }^{98}$ For this anti-Somaliland narrative, he would have faced arrest if he ever went to Somaliland without retracting his statements. A third case came in May 2019 when a young Isaaq man wore the blue Somali national flag in the Hargeysa market. Photos of his arrest by the local police were disseminated on various anti-Somaliland websites. ${ }^{99}$ Six months later, in November, Farmaajo invited the young Isaaq man to Villa Somalia (the presidential palace) in Mogadishu to give him an award for his bravery. ${ }^{100}$

The developments in Somaliland suggest that the unity of a people cannot be maintained solely on the basis of past political memory, however charged. Rather, the state has to serve a purpose in the present. In other words, the state must deliver social services and development. Young people in Hargeysa are to some extent proud of their city, but they also share with their counterparts in Mogadishu and elsewhere in southern Somalia the push to emigrate to Europe via the Mediterranean Sea to make a living. ${ }^{101}$ The fact that Somaliland possesses no major industries that could lessen unemployment exacerbates the situation. Somaliland authorities seek to overcome their lack of natural resources by negotiating with Arab investors from the Gulf States to create local jobs. An acute condition of unemployment exists because since 1991, preoccupation with separation has isolated Somaliland's people from the rest of Somalia even in terms of resource-sharing, making the gap between the haves and

97 "Somaliland oo xukuntay Gabar Abwaanad aheyd," Midnimo, accessed 9 September 2018, http://midnimo.com/2018/04/15/somaliland-oo-xukuntay-gabar-abwaanad-aheyd/.

98 "Siyaad Barre geesi waddaniya ayuu ahaa, Allaah hawnaxariisto," (between min. 0:13-18:50), accessed 13 September 2018, https://www.youtube.com/watch?v=te55 tOPLtoU; and "Taariikhdii M, Siyaad Barre qaybtii 2 AAD," (between min. 0:13-29:21), accessed 13 September 2018, https://www.youtube.com/watch?v=IS2ewjxdT54.

99 "Daawo Sawirro: Madaxweyne Farmaajo oo caawa la kulmay Wiilkii Hargeysa loogu xiray dareyska Somaliya," Halqaran.com, 20 November 2019; and "MUUQAAL: Wiilkii Hargeisa Calanka Loogu xidhay oo ka Warbixiyey Soo Dhowayntii Madaxwayne Farmaajo,” Kalshaale.ca, 21 November 2019.

100 "Wiil ku labistay dhar laga sameeyey calanka Soomaaliya oo maanta la xidhay," Hiiraan Online, 14 May 2019.

101 Field interviews, Hargeysa, July-August 2016 and April-May 2018. 
have-nots in Somaliland much wider than in southern Somalia. ${ }^{102}$ Due to poor infrastructure, water and electricity are only available to affluent families who have access to state resources or private companies. Both Somaliland and southern Somalia rank as two of the poorest states in Africa.

Somaliland has also witnessed a worsening security condition, especially in the eastern part of the country. Recurring armed conflicts between the Isaaq and the non-Isaaq, but also within the Isaaq, became a daily feature of life. The extent of the insecurity reached worrisome levels when a colonel in the Somaliland army defected with his forces in 2018 and declared the establishment of an armed rebel front in eastern Somaliland. Colonel Said Awil Jama, better known as Colonel Aarre, a Habar Yoonis commander, fell out with Somaliland military leaders in Hargeysa whom he accused of clannism - the tendency to favour their clans at the expense of other clans. ${ }^{103}$ Aarre himself was accused by the Somaliland military commanders of killing ten civilians and embezzling the salaries of the forces he had commanded. Aarre denied any wrongdoing and instead emphasised his role as one of the initial founders of the Somaliland army. ${ }^{104} \mathrm{~A}$ viable peace-building process was agreed upon between the two sides of the Isaaq clan to avert armed political conflict among them, yet Aarre's forces reengaged in some parts of the eastern Somaliland between 2018 and 2019. A deterioration of security was not only negatively affected local conditions; it threatened to erode international goodwill and recognition of Somaliland that depended on having a largely peaceful process of state-building. ${ }^{105}$

\section{Conclusion}

Post-colonial Somalia was a society that endured prolonged armed conflict that ravaged the once unified state. Riven by a brutal civil war consisting of years of inter- and intra-clan conflicts, exacerbated by contestation of the commemoration of historical grievances, war-torn Somalis came up with various political memories to secure divergent political positions of power. As Besteman stated: "Anthropologists recognize that memories play tricks, that current experiences reshape recollections of past events, and that stories are told with an eye to their possible future significance." ${ }^{106}$ Leaders in Somaliland provided a political

102 Ibid.

103 “Colonel Caarre oo iska difaacay eedo loo jeediyey,” Voasomali, 28 August 2019.

104 Ibid.

105 Field interviews, Hargeysa, July-August 2016 and April-May 2018.

106 Besteman, Making Refuge, 30. 
memory designed to cement unity among the Isaaq and sustain the existence of a separate state. It started its statehood as a "negotiated state" or a "mediated state" that developed into a state system combining modern and traditional modes of authority. ${ }^{107}$ In front of the international community, historical grievances gave legitimacy to the Somaliland insistence on becoming a separate state from Somalia. ${ }^{108}$ The Somaliland state came into being on the basis of a shared memory of political victimhood experienced by the Isaaq clan. This historical grievance will pose a challenge for any future rapprochement for the two nations. Negotiated solutions to the political conflicts among the clans, especially the separation project, failed to capture the confidence of non-Isaaq clans who had been erased from the common political memory over past events, especially of the Siad Barre regime, being disseminated by Isaaq elites. The fact that Somaliland remains unrecognised internationally after nearly three decades reinforces Somaliland authorities' frustration with the status quo. In official discourse and local news media in Hargeysa, Somalia is a foreign country with which the 'Republic of Somaliland' wishes to maintain international relations. Conversely, whilst exercising no real control or authority over Somaliland, the Somali Federal Government in Mogadishu attempts to maintain the juridical illusion that Somaliland remains, after all, part and parcel of Somalia. The future will determine how these two contradictory present and past positions will be settled.

Historians writing about the recent past encounter different challenges than those who write about the distant past. People tend to become easily agitated or excited over the recent past or contemporary history. For instance, as Jonah Rubin points out in a case of memory politics in contemporary Spain, "people enact memory politics not only by contesting narratives of the past, but also, first and foremost, by dis- and reassembling the physical, institutional, and social entanglements that undergird democratic politics." ${ }^{109}$ In his personal history

107 Tobias Hagmann and Didier Péclard, "Negotiating Statehood: Dynamics in Power and Domination in Africa," Development and Change 41, no. 4 (2010): 539-562; Marleen Renders and Ulf Terlinden, "Negotiating Statehood in a Hybrid Political Order: The Case of Somaliland," Development and Change 41, no. 4 (2010): 723-746; and Ken Menkhaus, "The Rise of the Mediated State in Northern Kenya: The Wajir Story and its Implications for State-building," Africa Focus 21, no. 2 (2008): 23-38.

108 Brian J. Hesse, "Lessons in Successful Somali Governance," Journal of Contemporary African Studies 28, no. 1 (2010): 71-83; and Brian J. Hesse, "Where Somalia Works," Journal of Contemporary African Studies 28, no. 3 (2010): 343-362.

109 Jonah S. Rubin, "How Francisco Franco Governs from Beyond the Grave: An Infrastructural Approach to Memory Politics in Contemporary Spain,” American Ethnologist 45, no. 2 (2018): 214-227. For how this was the case in other contexts, see T. Fujitani, Geoffrey M. White and Lisa Yoneyama (eds.), Perilous Memories: The Asia-Pacific War(s) (Durham, Duke University 
of the post-Biafra period, Chinua Achebe contended that victims of violent African conflicts "are often too ready to let bygones be bygones."110

However, this was not the case in Somaliland where memories of the horrors of the Siad Barre regime still remain present in the minds of most Isaaq people. A sustainable peace between Somaliland and southern Somalia will only succeed when Isaaq historical grievances are adequately addressed. As Geshekter pointed out, "[t]he memories of the real Siad Barre regime atrocities will not soon be forgotten in Somaliland. The revivalist/reconstructionist energies seem mainly in the south. The north says 'no more Mogadishu.' The world does not know what to do except try and put the fractured, shattered, broken state back together again." "111 Though some Isaaq people disagree with the formation of the Somaliland state (its separation from southern Somalia), very few want to negotiate with Mogadishu as to the rightfulness of the existence of the state in Somaliland representing a clan identity as Isaaq, but rather as members of a broader Somaliland community.

Writing about Somalia in the 1990s, Simon Horner inquired about whether the Somali "jigsaw" - in this case, the chronic conflict - could be pieced together. ${ }^{112}$ This chapter has explored the intersection between political memory and state-building projects in post-conflict Somalia. The theme of political memory is an important one, yet it is largely ignored in studies of Somali state-building. The chapter has addressed post-conflict contexts to understand many forms of grievance-based political memory. The recollections of many Somalis camouflage the roots of clan conflicts and the cataclysms caused by the Siad Barre regime. Siad Barre's regime, not unlike the regime of Daniel arap Moi in Kenya, was remembered by many in Somaliland as "a depressing time of political oppression, mismanagement of resources, rising insecurity and increasing corruption.” But in southern Somalia people vary between having positive and negative recollections of the era. ${ }^{113}$ These divergent political memories have deeply divided inter- and intra-clans, thus illustrating how post-conflict historical grievances generate political divisions among the communities living in Somaliland and southern Somalia. Somaliland was created using a conscious construction of

Press, 2001); and Jay Winter, Remembering War: The Great War between Historical Memory and History in the Twentieth Century (New Haven: Yale University Press, 2006).

110 Chinua Achebe, There Was A Country: A Personal History of Biafra (London: Penguin Books, 2012), 49.

111 Charles Geshekter, email communication, 24 April 2013.

112 Simon. "Somalia," 46-53.

113 Jeong Kyung Park, "Blaming the Moi Era: Memories of Bad Governance among Eastlands Residents in Nairobi, Kenya,” Memory Studies (2018): 691-707. 
past historical grievance to drive the separate state-building project towards attracting international recognition. Past and present grievances illuminate political realities in Somaliland which were primarily built upon political memory that drew from the legacies of the military rule.

\section{Bibliography}

"21 Oct.Taariikhdii kacaanka iyo khudbadihi ugu muhiimsana Madaxweyne Siyaad. Keydka R/muqdisho.DHAGEYSO," Radio Muqdisho, 22 October 2015, accessed 9 September 2018, https://www.radiomuqdisho.net/21-oct-taariikhdii-kacaanka-iyo-khudbadihi-ugu-mu hiimsana-madaxweyne-siyaad-keydka-rmuqdisho-dhageyso/.

Abdullahi, Mohamed Diriye. "In the Name of the Cold War: How the West Aided and Abetted the Barre Dictatorship of Somalia." In Genocide, War Crimes \& The West: History and Complicity, edited by Adam Jones, 241-259. London: Zed Books, 2004.

Achebe, Chinua. There Was A Country: A Personal History of Biafra. London: Penguin Books, 2012.

Africa Watch. Human Rights Abuses and Civil War in the North: A Report from the U.S. General Accounting Office. New York, Africa Watch, 1989.

Africa Watch. A Government at War with Its Own People: Testimonies About the Killings and the Conflict in the North. New York, Africa Watch, 1990

Amadiume, Ifi, and Abdullahi An-Na'im, eds. The Politics of Memory: Truth, Healing \& Social Justice. London: Zed Books, 2000.

Adan, Amina H. "Somalia: An Illusory Political Nation-State." South Asia Bulletin 14, no. 1 (1994): 99-109.

Amnesty International. Somalia: A Long-Term Human Rights Crisis. New York: Amnesty International, 1988.

Amnesty International. Somalia: Imprisonment of Members of the Isaaq Clan Since Mid-1988. New York: Amnesty International, 1988.

Anon. "It is impossible to Disdain People's Memory, Mr President." KAAH, A Periodical Journal of the Ogaden National Liberation Front 111 (July 1988): 15-17.

“Baladweyne: Qaxootigii Ogaadeenka oo Ciidam[a]da Maxamad Siyaad Barre ay Hubeeyeen!” Keydmedia, accessed 26 July 2014, http://www.youtube.com/watch?v=Dt1pqsZ2R-I.

Bakonyi, Jutta. "Moral Economies of Mass Violence: Somalia 1988-1991," Civil War 11, no. 4 (2009): $434-454$.

Besteman, Catherine. Making Refuge: Somali Bantu Refugees and Lewiston, Maine. Durham: Duke University Press, 2016.

Bjork, Stephanie R. Somalis Abroad: Clan and Everyday Life in Finland. Chicago: University of Illinois Press, 2017.

Box 4, folder "Somalia - President Mohammed Siad Barre" of the National Security Adviser's Presidential Correspondence with Foreign Leaders Collection at the Gerald R. Ford Presidential Library.

Cable from US Embassy in Mogadishu to Washington. "Sub: Peace Breaking Out in the North?.” Accessed 31 August 2014, https://wikileaks.org/cable/1990/03/90MOGA DISHU2527.html. 
Cassanelli, Lee. "Reconciliation and Reconstruction: Are there Lessons from Somalia's [R] ecent History?," paper presented at the 6th International Congress of Somali Studies, Berlin, December 6-9, 1996.

“Colonel Caarre oo iska difaacay eedeo loo jeediyey," Voasomali, 28 August 2019.

Compagnon, Daniel. "The Somali Opposition Fronts: Some Comments and Questions," Horn of Africa 13, no. 1-2 (January-June 1990): 29-54.

Compagnon, Daniel. “Dynamiques de Mobilisation, Dissidence Armée et Rébellion Populaire: Le Cas du Mouvement National Somali (1981-1990)," Africa 47, no. 4 (1992): 502-530.

Compagnon, Daniel. "Somaliland, un Ondre Politique en Gestation?," Politique Africain 50 (June 1993): 9-20.

Compagnon, Daniel. "Somali Armed Movements: The Interplay of Political Entrepreneurship and Clan-Based Factions." In African Guerrillas, edited by Christopher Clapham, 73-89. Oxford: James Currey, 1998.

Compagnon, Daniel. "State-sponsored Violence and Conflict under Mahamed Siyad Barre: the Emergence of Path Dependent Patterns of Violence," World Peace Foundation Occasional Papers, October 22, 2013, accessed 23 December 2013, http://sites.tufts.edu/re inventingpeace/2013/10/22/state-sponsored-violence-and-conflict-under-mahamed-siyadbarre-the-emergence-of-path-dependent-patterns-of-violence/.

Confidential Cable. "Two Views on Somaliland: Hostile Forces Target Economy, No Return to a Unified Somalia." U.S. Embassy in Djibouti to the State Department in Washington, 6 August 2017, accessed 20 December 2020, https://web.archive.org/web/ $20160328033823 /$ http://cables.mrkva.eu/cable.php?id=118293.

"DAAWO SAWIRRO: Madaxweyne Farmaajo oo caawa la kulmay Wiilkii Hargeysa loogu xiray dareyska Somaliya," Halqaran.com, 20 November 2019.

"Daawo Xukuumada Somaliland Oo Ka Hadashay Dagaal Khasaaro Gaystay Oo ka Soo Cusboonaaday Ceel-af-wayn,” Lughaya, accessed 9 September 2018, http://www.lughaya. com/home/2018/07/24/daawo-xukuumada-somaliland-oo-ka-hadashay-dagaal-khasaarogaystay-oo-ka-soo-cusboonaaday-ceel-af-wayn/.

David, Lee. "Holocaust and Genocide Memorialisation Policies in the Western Balks and Israel/Palestine." Peacebuilding 5, no. 1 (2017): 51-66.

Declich, Francesca. "When Silence Makes History, Gender and Memories of War Violence from Somalia." In Anthropology of Violence and Conflict, edited by Bettina Schmidt and Ingo Schröder, 161-175. London: Routledge, 2001.

Djama, Marcel. "Sur la Violence in Somalie: Genése et Dynamique des Formations Armées." Politique Africaine 47 (1992): 147-152.

Document. "Qaab-Dhismeedka Ciidanka Qaranka Somaliland, Hogaamada ciidanka iyo beelaha ay ka soo jeedaan." September 2016.

“Documentary - Taariikh Nololeedka Cabdilaahi Koongo Qaybtii 9aad.” Accessed 26 August 2014, https://www.youtube.com/watch?v=36e9oM90r7Q.

“Documentary - Taariikh Nololeedka Cabdilaahi Koongo Qaybtii 10aad.” Accessed 26 August 2014, https://www.youtube.com/watch?v=EsANwflCoYM.

“Documentary - Taariikh Nololeedka Cabdilaahi Koongo Qaybtii 11aad.” Accessed 26 August 2014, https://www.youtube.com/watch?v=-1s7DkF1T2E.

“Documentary - Taariikh Nololeedka Cabdilaahi Koongo Qaybtii 12aad.” Accessed 26 August 2014, https://www.youtube.com/watch?v=pMNZSVWRF_c. 
Dool, Abdullahi. “Good Governance: Self-Administering Regions within a Democratic Union." Somalia 4 (June 2001): 5-36.

Ellis, Stephen. "The Mutual Assimilation of Elites: The Development of Secret Societies in Twentieth Century Liberian Politics." In The Powerful Presence of the Past: Integration and Conflict along the Upper Guinea Coast, edited by Jacqueline Knörr and Wilson Trajano Filho, 185-204. Leiden: Brill, 2010.

Englebert, Pierre. Africa: Unity, Sovereignty \& Sorrow. Boulder, Colo.: Lynne Rienner Publishers, 2009.

Fazal, Tanisha M. "Go your Own Way: Why Rising Separatism Might Lead to More Conflict." Foreign Affairs (July-August 2018): 113-123.

Fujitani, T., Geoffrey M. White and Lisa Yoneyama, eds Perilous Memories: The Asia-Pacific War(s). Durham, Duke University Press, 2001.

"Gabadh re[er] Burco ah oo Jawab Kulul siisay Islantii Farmaajo werartay," Daljire, accessed 11 December 2017, https://www.youtube.com/watch?v=0ID7RAD553s.

“Gabadh re[er] Hargaysa oo Somaali Jacayl la ilmaysa," Daljire, Accessed 11 December 2017, https://www.youtube.com/watch?v=4-QUNrBeaOl\&feature=youtu.be.

"Gabdho Reer Hargaysa ah oo Amaan Kala Dul dhacay Muqdisho lyo Somali Weyn." Cagaaran, accessed 11 December 2017, https://www.youtube.com/watch?v=Her3UPmpJs.

“General Mohamed Ali Samatar, 1931-2016," Journal of the Anglo-Somali Society 60 (Autumn 2016): 62.

Gersony, Robert. Why Somalis Flee: Synthesis of Accounts of Conflict Experience in Northern Somalia by Somali Refugees, Displaced Persons and Others. Washington: State Department, 1989.

Gersony, Robert. "Why Somalis Flee: Conflict in Northern Somalia." Cultural Survival Quarterly 13, no. 4 (1989): 45-58.

Geshekter, Charles. Email communication, 24 April 2013.

Hagmann, Tobias, and Didier Péclard. "Negotiating Statehood: Dynamics in Power and Domination in Africa." Development and Change 41, no. 4 (2010): 539-562.

Hesse, Brian J. "Lessons in Successful Somali Governance." Journal of Contemporary African Studies 28, no. 1 (2010): 71-83.

Hesse, Brian J. "Where Somalia Works." Journal of Contemporary African Studies 28, no. 3 (2010): 343-362.

Horner, Simon. "Somalia: Can the Jigsaw be Pieced Together." ACP-EU Courier 162 (1997): 46-53.

Hills, Alice. "Somalia Works: Police Development as State building." African Affairs 113, no. 945 (2014): 88-107.

Ingiriis, Mohamed Haji. The Suicidal State in Somalia: The Rise and Fall of the Siad Barre Regime, 1969-1991. Lanham: University Press of America, 2016.

Ingiriis, Mohamed Haji. "How Somalia Works: Mimicry and the Making of Mohamed Siad Barre's Regime in Mogadishu.” Africa Today 63, no. 1 (2016): 57-83.

Ingiriis, Mohamed Haji. “'We Swallowed the State as the State Swallowed us': The Genesis and Genealogies of Genocide in Somalia." African Security 9, no. 3 (2016): 237-258.

Ingiriis, Mohamed Haji. "Many Somalia(s), Multiple Memories: Remembrance as Present Politics, Past Politics as Remembrance." African Identities 14, no. 1 (2016): 348-369. 
Ingiriis, Mohamed Haji. "Who Assassinated the Somali President in October 1969?: The Cold War, the Clan Connection or the Coup d'État." African Security 10, no. 1 (2017): 1-24. Ingiriis, Mohamed Haji. "Between the Devil and the Deep Blue Sea: The Birth and the Breakdown of the Somali Armed Movements, 1976-1999." In National Liberation Movements as Governments in Africa, edited by Redie Bereketeab, 233-248. London: Routledge, 2017.

Ingiriis, Mohamed Haji. "State Violence and Clan Violence in Somalia." African Conflict and Peacebuilding Review 8, no. 1 (2018): 73-96.

Ingiriis, Mohamed Haji. "Clan Politics and the 2017 Presidential Election in Somaliland." Journal of Somali Studies 4, no. 1-2 (2018): 117-133.

Ingiriis, Mohamed Haji. "From Pre-Colonial Past to the Post-Colonial Present: The Contemporary Clan-Based Configurations of Statebuilding in Somalia." African Studies Review 61, no. 2 (2018): 55-77.

Kaiser, Susana. "Escraches: Demonstrations, Communication and Political Memory in Post-Dictatorial Argentina." Media, Culture and Society 24, no. 4 (2002): 499-516.

Keen, David. Conflict \& Collision in Sierra Leone. Oxford: James Currey, 2005.

"Khudbad Muuse Biixi Cabdi," Somaliland Television, 8 March 2018.

MacArthur, Julie. Cartography and the Political Imagination: Mapping Community in Colonial Kenya. Athens, Ohio: Ohio University Press, 2016.

"Madaxwayne muuse biixi oo dumar ka ooy siiyay + xuska 8march," Hadhwanaag News, March 8, 2018.

Mayer, Arno J. The Furies: Violence and Terror in the French and Russian Revolution. Princeton: Princeton University Press, 2000.

Mayo, James M. "War Memorials as Political Memory." Geographic Review 78, no. 1 (1988): $62-75$.

Mekonnen, Daniel. "Contested Versions of Collective Memory in Postindependence Eritrea." African Conflict \& Peacebuilding Review 3, no. 2 (2013): 151-170.

Menkhaus, Ken. "The Rise of the Mediated State in Northern Kenya: The Wajir Story and its Implications for State-building." Africa Focus 21, no. 2 (2008): 23-38.

Menkhaus, Ken. "Review: Clan Cleansing in Somalia: The Ruinous Legacy of 1991 by Lidwien Kapteijns. Philadelphia, PA: University of Pennsylvania Press, 2013.” The Journal of Modern African Studies 52, no. 2 (2014): 679-681.

“Move by Hassan Sheikh Unites Somaliland Tribes Against Him.” The Indian Ocean Newsletter, no. 1429, 17 June 2016.

"MUUQAAL: Wiilkii Hargeisa Calanka Loogu xidhay oo ka Warbixiyey Soo Dhowayntii Madaxwayne Farmaajo," Kalshaale.ca, 21 November 2019.

Nagengast, Carole. "Violence, Terror, and the Crisis of the State." Annual Review of Anthropology 23 (1994): 109-136.

Niemann, Michael. "War Making and State Making in Central Africa." Africa Today 53, no. 3 (2007): 21-39.

Park, Jeong Kyung. "Blaming the Moi Era: Memories of Bad Governance among Eastlands Residents in Nairobi, Kenya.” Memory Studies (2018): 691-707.

Philips, Sarah G. "Proximities of Violence: Civil Order Beyond Governance Institutions." International Studies Quarterly 63, no. 3 (2019): 680-691.

“Pointers - Somalia: Siad Barre’s Foes.” Africa Confidential 22, no. 9 (April 22, 1981): 7. 
"Prof. Ahmed Ismail [S]amatar (Somaliland waa muqadas) oo ka soo laabtey Hargaysa." Accessed 20 July 2016, https://www.youtube.com/watch?v=cSfjo8KPZCU.

Prunier, Gérard. "A Candid View of the Somali National Movement." Horn of Africa 13-14: no. 3-4 \& no. 1-2 (1990): 107-120.

Renan, Ernest. "What is a Nation." In Nation and Narration, edited by Homi K. Bhabha, 8-22. London: Routledge, 1990.

Renders, Marleen. Consider Somaliland: State-Building with Traditional Elders and Institutions. Leiden: Brill, 2012.

Renders, Marleen, and Ulf Terlinden. "Negotiating statehood in a hybrid political order: The case of Somaliland," Development and Change 41, no. 4 (2010): 723-746.

Rettig, Max. "Gacaca: Truth, Justice, and Reconciliation in Postconflict Rwanda." African Studies Review 51, no. 3 (2008): 25-50.

Rubin, Jonah S. "How Francisco Franco Governs from Beyond the Grave: An Infrastructural Approach to Memory Politics in Contemporary Spain." American Ethnologist 45, no. 2 (2018): $214-227$.

Samatar, Ahmed I. "I. M. Lewis, A Modern History of the Somali: Nation and State in the Horn of Africa. Athens: Ohio University Press, 2002." H-Net Reviews, December 2013, accessed 27 December 2016, https://www.h-net.org/reviews/showpdf.php?id=8552.

Samatar, Ibrahim Megag. "Light at the End of the Tunnel: Some Reflections on the Struggle of the Somali National Movement." In Mending Rips in the Sky: Options for Somali Communities in the 21st Century, edited by Hussein M. Adam and Richard Ford, 21-48. Lawrenceville, N.J.: The Red Sea Press, 1997.

Samatar, Said S. "How to Run an SNM Gauntlet." Horn of Africa 13, no. 1-2 (April \& June 1990): $78-87$.

"Sh. Xasan Daheeye oo ka sheekaynaya xasuuqii SNM ka samaysay Boorama." Accessed 13 September 2018, https://www.youtube.com/watch?v=_-iNyr28420.

Simmons, Michael. "Thousands of Somalis Reported Dead in Genocide Attacks." The Manchester Guardian Weekly, 15 January 1989.

"Siyaad Barre geesi waddaniya ayuu ahaa, Allaah hawnaxariisto." Accessed 13 September 2018, https://www.youtube.com/watch?v=te55tOPLtoU.

"Somali Military Bid to Obliterate Clan as Barre Era Fades," The Times, July 2, 1987.

"Somali National Movement." Accessed 20 May 2014, http://www.youtube.com/watch?v=XWo siLB6YNg.

"Somali Troops in Massacres and Bombings," The Guardian, June 24, 1988.

"Somalia: Barre Hangs on." Africa Confidential 24, no. 5 (1983): 5-7.

"Somalia: Civilians Massacred." The Indian Ocean Newsletter, February 27, 1988, no. 321.

"Somalia: Confused Situation Persists." The Indian Ocean Newsletter, no. 405 (11 November 1989).

“Somalia: Generals on the Move." Africa Confidential 25, no. 10 (1984): 7-8.

"Somalia: The Forgotten Men," New African, (April 1988).

"Somalia: The Ogadeni's Misfortune." Africa Confidential 25, no. 21 (1984): 5-7.

"Somalia: Tango in the Ogaden." Africa Confidential 27, no. 11 (1986): 3-5.

"Somalia: Thousands Dead." The Indian Ocean Newsletter, no. 340 (9 July 1988).

"Somaliland oo xukuntay Gabar Abwaanad aheyd," Midnimo. Accessed 9 September 2018, http://midnimo.com/2018/04/15/somaliland-oo-xukuntay-gabar-abwaanad-aheyd/. 
“Taariikhdii m, siyaad barre qaybtii 2 aad.” Accessed 13 September 2018, https://www.you tube.com/watch?v=IS2ewjxdT54.

The Center for Justice and Accountability, “Mass Atrocities in Northern Somalia: Warfaa V. Ali (Col. Tukeh)." Accessed 13 September 2018, https://cja.org/what-we-do/litigation/war faa-v-ali-col-tukeh/.

The Republic of Somaliland, "Submission on Statehood and Recognition of Republic of Somaliland." Hargeisa, June 1996.

“Thousands Flee as Somali Soldiers Massacre Civilians," The Observer, (3 July 1988).

Walls, Michael. "Liberation Struggle for Regime Change: Somaliland's Transition from Conflict to Civilian Government." In National Liberation Movements as Governments in Africa, edited by Redie Bereketeab, 218-232. London: Routledge, 2017.

Wertz, Megan. "Country Profile: Somaliland," Journal of Conventional Weapons Destruction, 10, no. 1 (2006): 38.

"Wiil ku labistay dhar laga sameeyey calanka Soomaaliya oo maanta la xidhay," Hiiraan Online, (14 May 2019).

Winter, Jay. Remembering War: The Great War between Historical Memory and History in the Twentieth Century. New Haven: Yale University Press, 2006.

"Xasuuqii ka dhacay arabsiyo xiligii kaidii taliska Siyaad Bare." Arabsiyo News, accessed 11 December 2017, https://www.youtube.com/watch?v=LB3K0UjoCKO. 